Portland State University

PDXScholar

$5-1-1969$

\title{
The view from the future; the self-fulfilling prophecy as an element in historical causation
}

William Welker Lenon

Portland State University

Follow this and additional works at: https://pdxscholar.library.pdx.edu/open_access_etds Let us know how access to this document benefits you.

\section{Recommended Citation}

Lenon, William Welker, "The view from the future; the self-fulfilling prophecy as an element in historical causation" (1969). Dissertations and Theses. Paper 910.

https://doi.org/10.15760/etd.910

This Thesis is brought to you for free and open access. It has been accepted for inclusion in Dissertations and Theses by an authorized administrator of PDXScholar. Please contact us if we can make this document more accessible: pdxscholar@pdx.edu. 
AN ABSTRACT OF THE THESIS OF William Welker Lenon for the Master of Arts in History presented May 23, 1969.

Title: The View From the Future - The Self-fulfilling Prophecy - As An Element in Historical Causation

APPROVED BY MEMBERS OF THE THESIS COMMITTEE:

Jarnes F. Heath, Chairman

Whitney $\mathrm{K} /$ Bates

Michael F. Reardon

The behavioral sciences in conjunction with history provide a unique opportunity for a more creative, yet precise, approach to the role of man as an historical and social agent. On the one hand history provides an approach to man's role based on the appeal to both facts and creative interpretation. On the other, the behavioral sciences can provide historians with a more precise concept of the mechanism of social, cultural, and personal role development and action. The creative conjunction of the behavioral sciences and history is called Neo-synthecism in order to more easily identify this approach. There are two purposes to this essay: to show both the general utility of a behavioral approach to history, and the specific role of the selffulfilling prophecy. 
The self-fulfilling prophecy, derived from the work of sociologist, Robert K. Merton, demonstrates how men tend actively to fulfill and objectify the expectations they hold for themselves. Thus men attempt both consciously and unconsciously to fulfill their own prophecies. The data upon which this approach is based is primarily of an interpretive nature. It briefly explores how individual scholars have implicitly assumed the idea of the self-fulfilling prophecy in the course of their writing. Most historians unconsciously utilize the concept without identifying or recognizing it as a specific behavioral function of men, and their activities, in general. Further, the essay investigates the idea of national character and social myth as factors which the self-fulfilling prophecy both contributes to and is dependent upon.

Neo-synthecism, while not a total explanation of the "why" of history does help to account for some of its "mysteries." It can, for instance, through the behavioral approach, help to explain the role of the irrational as a causative historical factor. It also helps to explain the mechanisms which prompt men to revolutionary action. Thus it can penetrate the background of historical events more fully. At the same time it provides the historian with a new instrument for understanding the future as well as the past. That is, in explaining one of the mechanisms whereby men control and modify events to suit their own beliefs, it enables historians to understand why particular expectations can or cannot be fulfilled. In one sense then the historian looks back from the "future" into the past and predicts the predominance of one historical event over another. 
Neo-synthecism, however, is a theory based upon suspended judgment. It holds its interpretation in abeyance of the future's verdict and is instructed by, events. 
THE VIEW FROM THE FUTURE - THE SELF-FULFILLING PROPHECY AS AN ELEMENT IN HISTORICAL CAUSATION

by

William Welker Lenon

A thesis submitted in partial fulfillment of the requirements for the degree of

\author{
MASTER OF ARTS \\ in \\ HISTORY
}

Portland State University

1969 
TO THE OFFICE OF GRADUATE STUDIES:

The members of the Committee approve the thesis of William Welker Lenon presented May 23, 1969.

Janies F. Heath, Chairman
Whitney K. Bates

Michae1 F. Reardon

APPROVED:

-

$n \cap n$

Jesse I. Gilmore, Head, Department of History

Wavid Malcolim, Acting Dean of Graduate Studies
May 23, 1969 
TABLE OF CONTENTS

PAGE

CHAPTER

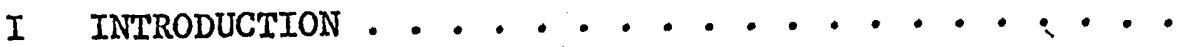

II THE VIEW FROM THE FUTURE . . . . . . . . . •

The "Thomas Theorem" and the Self-

fulfilling Prophecy... . . . . . . . .

III PATTERNS

Studies in the Self-fulfiling

Prophecy. . . . . . . . . . • • • •

IV MYTH, HISTORY, AND THE FUTURE. . . . . . . .

$\mathrm{V}$ IMPLICATIONS..$\cdot \cdot \cdot \cdot \cdot \cdot \cdot \cdot \cdot \cdot \cdot \cdot \cdot \cdot \cdot$ 


\title{
CHAPTER I
}

\section{INTRODUCTION}

\author{
History can be made. It is not \\ necessary to receive it as mere \\ destiny. \\ Gunnar Myrdal
}

\begin{abstract}
We live...lives based upon selected fictions. Our view of reality is conditioned by our position in space and time-not by our personalities as we like to think.
\end{abstract}

Lawrence Durrell

Ideas, not unlike good wines, need time not necessarily to mellow, but at least to age. The ideas presented herein may be "underaged" (or perhaps may have even "gone sour"!) but are no less important or deserving of attention or elaboration. While my particular approach may. not bring to the subject the necessary intelligence of explication and elaboration (this judgment I leave to the reader) something must be said of these ideas to at least clear the field for future work.

My intention in this essay is to promote, in some small way, the inter-utility of the behavioral'sciences with history and vice-versa. In doing so, however, I do not propose to once again lead history to uncritical worship at the altars of science. George Gaylord Simpson has said that:

The present chaotic stage of humanity is not, as some wishfully maintain, caused by lack of faith but by too much unreasoning faith within these boundaries where such faith should have no place. 1 
It is in the name of just such an attempt (i.e. the elimination of unreasoning faith) that contemporary scholars have made giant strides in the name of reason (or at least rationality). Unfortunately, what many, but by no means a11, have been gurilty of is a kind of "unreasoned faith" in reason itself. The effect is ultimately not unlike being one of the faithful of the religious variety. Both sometimes forget that the basis of their respective views of reality rely on an equally tenuous foundation of assumptions and pre-suppositions. Specifically, what "rational man" often neglects in his attempts at "definition" is that corollary to reason in every man which is called the "irrational". It is, in one sense, the concern of this essay to elaborate on just what the element of the irrational has to do with historical process. But in another and deeper sense it is also to show the relationship that exists both inadvertently and consciously between historical process and man's ability to in some way shape his future. At base what this means is that man is ultimately responsible with regard to the individual and to the outcome of his society at large. It must be stressed, therefore, that this essay is not an "end" in any sense of the word. On one level it is a statement of purpose; on another it is a statement of future intent.

Hopefully the behavioral sciences, and specifically sociology and psychology, will offer a direction to the study of man that seems for the most part unexamined. And while I have let the behavioral sciences direct, I have not let them lead. History, being "...temporally removed in the occasion of its event[j] ${ }^{2}$ cannot be dictated to. Interpretation is, however, a different matter, and as I tend to think 
in terms of the historian, I have chosen my direction of interpretation accordingly. Let it not be disparaging of, or to, the behavioral scientist. Each of us must choose.

In the following essay, I will be concerned not so much with historical sequence as I will be with the nature of particular interpretations and their relative importance to my thesis. In the same manner I will be less concerned with events than with what men have thought about those events. For it is not the intelligent understanding of our past, in order to control the future, that must be the historian's primary concern. More importantly it is with the knowledge of man's capacity, both to control and be controlled, to be at once agent and objective observer, and to realize that he can never step "outside" of history's ebb and flow. Ultimately this must be his foremost consid- . eration.

Because this essay is primarily concerned with the mechanism and implications of the objectification of an historical and behavioral process, and not simply with facts per se, there is not a concentration or emphasis on primary research. The very nature of the problem lends itself more fully to interpretation and a certain amount of necessary speculation. One must also know the problem before he can solve it. 
CHAPTER II

THE VIEW FROM THE FUTURE

Twentieth Century historians are perhaps the strangest breed of scholars ever produced. They are caught in a dilemma of their own making. For while it is fashionable to decry causation in history, all appear to be looking for meaning; and meaning is, after all, only another word for the product of causal relationships. Certainly few historians will admit to anything more than relating: "wie es eigentlich gewesen." But, while it may be in bad taste to raise the question of causation in history, the "need" to find meaning, to explain the "why" of a particular event, remains as relevant as ever. Like death and defecation, causality is rarely spoken of directly. I will not only discuss and propose a theory of both direct and indirect causality in history, but also examine andillustrate how other scholars, not only historians, have often unwittingly and/or without full awareness of the forces involved, implicitly affirmed the existence of a particular and verifiable historical theory.

This approach will hopefully be more than cursory and less than comprehensive. It will, in the end, set the stage for a wider and more embracing approach to the social sciences through a broader understanding of a little known and little understood phenomenon derived from the work of the sociologist Robert $K$. Merton. This phenomenon is the "self-fulfilling prophecy"1 and it is to this we must first direct our attention. 
The "Thomas Theorem"

and

the Self-fulfilling Prophecy

Robert K. Merton, in his book Social Theory and Social Structure raises, almost indirectly, a theory of social causation which in its consequences extends far beyond the somewhat minor position that he relegates it to. Taking the Thomas theorem ("If men define situations as real, they are real in their consequences") ${ }^{2}$ as his basis, Merton expands the theorem into a definition of broad social action and reaction. Merton points out, with regard to the Thomas theorem, that it:

...provides an unceasing reminder that men respond not only to the objective features of a situation, but also, and at times primarily, to the meaning this situation has for them. And once they have assigned some meaning to the situation their consequent behavior and some of the consequences of that behavior are determined by the ascribed meaning. 3

How then does this apply to "real" situations? Merton illustrates the mechanism in a "Sociological Parable". 4 He describes a hypothetical banking failure and collapse in the early Thirties which was due to an objectification of expectations. In the case of Merton's "Last National Bank" example, the rumored insolvency of the bank becomes real insolvency when enough people believe the rumor to be true and attempt to salvage their earnings. Merton explains the failure thusly:

The stable financial structure of the bank had depended upon one set of definitions of the situation: belief in the validity of the interlocking system of economic promises men live by. Once depositors had defined the situation otherwise, once they questioned the possibility of having these promises fulfilled, the consequences of this unreal situation were real enough.

Merton goes on for nearly all of the remaining portion of his chapter to expose the elemtns of the Thomas theorem as it applies to the 
racial problem in America. This latter example, important as it may be, need not overly concern us at this juncture. What Merton says with regard to the self-fulfilling prophecy's mechanism itself is the important matter.

By way of further example let us "read out" the mechanism on a more individual level, for ultimately it is individual action which provides the "stuff of history." Let us assume that someone visits a so-called "fortune teller" and that during the course' of the evening the "seer" makes a prediction concerning events that are to transpire on the following day, and that among those events the "seer" foretells of an accident which is to take place in that person's living room on the next morning. In most instances the individual will shrug off this, prediction as humorous, but irreleyant, fantasy. In this case, however, the next morning, while nailing a picture to the wall, the individual falls off the stool he was on thus fulfilling the "fortune teller's" prophecy, albeit perhaps subconsciously. As Merton points out: "The self-fulfilling prophecy is, in the beginning, a false definition of the situation evoking a new behavior which makes the originally false conception come true. ${ }^{6}$ Thus, in our example, despite the individual's scoffing at the seer's prediction as false, it has none-the-less evoked a new series of behavioral reactions which have caused the essentially false prediction to "come true.": that is to say, the individual insures and produces his own accident. Merton continues, concerning such behavior, to say that: "The specious validity of the self-fulfilling prophecy perpetuates a reign of ferror. For the prophet will cite the actual course of events as proof that he was right from the very beginning." 7 
But need the validity of the self-fulfilling prophecy be specious in all circumstances? Or, are there, after all, circumstances in which the self-fulfilling prophecy leads to situations that are valid in themselves with regard to the predictions made about them? Can a people, a nation, or an entire civilization guide the course of its own destiny over the entire range of possible futures? These questions form the framework of what is to follow and act as arrows pointing in new directions of investigation. What then can we say of these questions? 
CHAPTER III

PATTERNS

I have chosen to call the objectification of the self-fulfilling prophecy in history "Neo-synthecism." My purpose in referring to the objectification of the self-fulfilling prophecy as "snythetic" is to present the role of the behavioral sciences (e.g. psychology and sociology) in a union with historical method.

Thus, the theory presented here is "synthetic" in that it is a partial synthesis of those several disciplines. The prefix "Neo-" has been affixed in order to avoid (hopefully) any connotation of the Hegelian "dialetic": that is, to prevent the mistake of viewIng this theory as a synthesis derived from a "thesis" and an "antithesis"; also, simply because it is a "new" theory of social and cultural causation.

Neo-synthecism is a theory of history based upon suspended judgment. Because the art and science of written history depends, no matter what the nature of causation may be, upon interpretation and creativity, as well as upon documentation and the appeal to facts, Neo-synthecism, as every true history must, holds its truths in abeyance of the future's Interpretive verdict.

Whereas a total theory of history would attempt to perhaps "read" from the future, as well as from the past, the Neo-synthetic theory makes no pretentions to that effect. With the contemporary state of 
the art being what it is, such an attempt would likely be futile. As the role of the historian broadens, however, such endeavors may eventually prove modestly successful. With computer aids, the several other sciences, a more "enlightened" approach to "contemporary history", and most importantly, an identification of the role of the self-fulfilling prophecy, certain future historical trends could be more effectively charted than is presently possible.

The question of future trends should at least be raised here, if not answered. (This problem will be dealt with, at least partially, in the final section.) What this attempt becomes, therefore, is one of exploration of the currents of historical process themselves. While not disregarding whatever "ends" history holds, neither does it become bound by them. Stated simply, Neo-synthecism is a theory of ongoing process and not of final or teleological ends.

\section{Studies in the Self-fulfilling Prophecy}

As has been noted, Neo-synthecism is a theory based upon suspended judgment. It is still, however, a gauge for social and cultural ambitions, hopes, and fears. Until the Renaissance, the idea of progress had been of relatively minor importance. The 16 th and 17 th centuries mark for the first time in human history the explicit idea of earthly progress. 1 It is also in the 17 th $^{\prime}$ century that the idea of "revolution" in the political sense was derived. ${ }^{2}$ Revolution hinges on the idea of progress. For without the hope of human betterment, there could be no projection of the aspirations of worldly political, social, and cultural improvement. The concept of revolution is, in fact, an 
explicit recognition of the idea that a man's thoughts and ideals must lie in the future to be relevant to the present. Miguel Unamuno, the Spanish philosopher has said that, "Everyone who fights for any ideal whatever, although his ideal may seem to lie' in the past, is driving the world on to the future." 3 . This generation of ideals, their projection, or "drive to the future," is the concretization of the selffulfilling prophecy. Thus, every true revolutionary utilizes the concept. While it is tempting to investigate the very obvious connections with Marxist revolutionary thought, I will touch only peripherally upon the subject as I primarily wish to concentrate on American history. (See appendix.)

Most instances of the self-fulfilling prophecy in history and in historical interpretation occur in such a manner as to be almost invisible, due to the obviousness of their operation. The American revolution, for instance, can be seen as a reaction, in terms of an economic and socio-ideological outlook, in which the vision of the future modified and directed the outcome. The colonials, prior to the early middle $1760^{\prime}$ s, for example, looked upon themselves almost exclusively as part and parcel of the British Empire. Expectations reflected in colonial literature prior to 1763 would seem to indicate that Americans considered themselves British in the full sense of the word. 4 The end of the French and Indian wars in 1763 and the resumption of Great Britain's attempt to reimpose its full supremacy over the colonies, modified colonial attitudes to the extent that the mother country became the symbol of repression rather than of tolerance and order. A case can certainly be made for the assumption that 
most colonials expected, at least until the mid-seventies, that America would remain in, and contribute to, Britain's "course of Empire." Indeed, it would seem that many colonials believed that America was only Britain outre-mer. However, when the full extent of British economic and political attitudes became known (or rather felt!) the colonials began to modify their views of the future. The seeds of the Constitution of 1787 were thus, in no small degree, sown in 1763. In its emphases on the written assurance of such things as no bills of attainder, no ex post facto legislation and the guarantee of habeas corpus, the constitution would be the embodiment of the break from England. No longer would Americans look upon Britain as mentor, but as suppressor. Events which shaped and directed Colonial resistance, such as the Boston Massacre were, in and of themselves, a reaction which constituted what the colonists wished the situation to be, rather than what was actually the case. The grievances listed by Thomas Jefferson in the Declaration of Independence, and directed against George III, in their intellectually emotional and almost literary. style are not, in a strict sense, real appeals to wrongs committed against the colonials. 5 More properly they are "projected" wrongs and affronts as seen by the colonials. Whether George III, for instance, could in reality be accused (as Jefferson did) of having as his "...direct object the establishment of an absolute tyranny over America/ ${ }^{16}$ is certainly moot.

Whether one regards the Revolution as an economic phenomenon or as an intellectual movement based upon "natural law," the fact remains that without a projection of possibilities into the future, 
without some very real expectations as to what the future was to be made to hold, and without a prophetic sense (or, if you will, mission) the revolution could not have taken place. John Adams argued, for example, that:

The prospect now before us in America, ought... to engage the attention of every man of learning, to matters of power and right, that we may be neither led nor driven blindfolded to irretrievable destruction. Nothing less than this seems to have been meditated for us, by somebody or other in Great Britain. There seems to be a direct and formal design on foot, to enslave all America.7

Thomas Paine also reflected this same sense of the future. Consider the following: "It is repugnant to reason, to the universal order of things, to all examples from former ages, to suppose, that this continent can longer remain subject to any external power. 8

Here is the writing of a man who not only has a "prophetic" sense of history, but is resolved that his view shall come to pass.

Once the commitment had been made to the basic cause of independence, the range of future horizons could be broadened widely: the Constitution and the Bill of Rights are the tangible results of that extended horizon. These two formative documents are ostensibly based upon principles of liberty and equality for all men. The preamble, for example, speaks in terms of "We the People...," implying an extension of freedom to more than just a single cross-section of the population. The Bill of Rights too mentions specifically (Articles I, II, and IV). "The right of the poeple"; not simply a specific social or political group, but again "the people". 9

In one sense, however, the abolitionist movement, the Civil War, the integration movements from Little Rock to the present, and the 
Civil Rights Acts of the $1960^{\prime}$ 's, are all attempts to fulfill the essential quality of prophecy embodied in the Constitution and Bill of Rights .

In 1943, Gunnar Myrdal, in his classic study An American Dilemma noted the prophetic and unfulfilled ideals of these two basic American documents. Myrdal pointed to what he called "the American Creed" (i.e. of the Constitution and Bill of Rights) and noted that as an ideal of social, political, and moral conduct, white (and black) Americans held a. set of values which professed equality, but promoted a fairly rigid state of inequality. Myrdal, in an unfortunately abbreviated manner, offered, as a solution to the racial problem, an intensification of the American Creed. The study showed quite clearly that the conditions of our Constitution and Bill of Rights were. unfulfilled. ${ }^{10}$

There is, of course, the obvious criticism to this line of reasoning that the founding fathers were both speaking and writing rhetorically. The argument states that the authors of the Constitution and the Bill of Rights had no real intention of ever extending the freedoms enumerated in these documents to large sections of the population, especially the black slave and non-property holding poor white. In effect the "natural law" which was deemed universal was so only to a fairly small, propertied, white male cross section of humanity. Universal "self-evident" truths, which men such as Thomas Jefferson and James Madison espoused, were to be limited, in reality, to a select "quasi-aristocracy" and middling class. Thus the proponents of this line of reasoning would point to the electoral college as an example of what the founding fathers truly had in mind. In this regard, the 
argument continues, they were motivated not by the extension of liberty to all men, or even to all Americans, but rather by "enlightened selfinterest." This position has much to recommend it, and may come close to the truth of the matter. The validity of the argument is, however, relatively unimportant with regard to the considerations being studied here. The important thing to note is the effect that the rhetoric, true or false, has had upon the American imagination.

If the founding fathers had no intention of extending liberty to all men, certainly succeeding generations of Americans at least have begun to do so. In part, the middle-class quest for security has prompted the fulfillment of the prophecy of the rhetoric of the Constitution and Bill of Rights. Impelled by fear of minority violence, which also represents a challenge to middle class supremacy, the middle-class has sought to extend the dominance of their position by incorporating other minorities into the political, economic, and social infrastructure they have built. The effort has thus been to submerge minority groups and dissenters by extending and projecting the rhetoric of freedom into reality. Constitutional rhetoric thus becomes a prophecy to be fulfilled, whether or not it ras originally intended to be such.

The intriguing problem for the historian becomes one of affixing a point in time when this rhetoric shifted into an attempt to live up to the challenge of its implications. One argument along these lines suggests that the threat of Fascism and Communism have presented Americans with a need to live up to the challenge of American rhetoric. ${ }^{11}$ Taken at face value this means only that certain conditions of the American philosophy need to be intensified and promoted. But the 
language of the Preamble, which explains the general aims of the Constitution, exhibits an attitude of "mission." It points to the future, to ..."our posterity..."12 and explains what can be expected in the extension of freedom to Americans under the protective aura of its enumerations. It is a prescription for the future, a contract with destiny, the terms of which are now finally forcing Americans to account. That we have not lived up to the terms of our basic Republican documents is obvious. There has been, as noted above, a tradition of American liberalism which has recognized this all along. It is this element in our society which has frequently attempted to rectify the inequalities generated by the traditionally individualistic white American. Democratic consent in America is an experiment unfulfilled. It has been, and remains, a picture of the future, a prediction which is based upon the Constitution and Bill of Rights; its principles and methods originally formulated by men such as James Madison, and refined further by Constitutional amendments over the last century and a half. The Constitution, a complex social charter which set up the political and legal limits of society, defended and promoted a particular view of the future. The Bill of Rights extended that view by insuring that certain individual and social prerogatives would remain inviolate. But the Revolution and $j$ ts attendant view of the future are only one aspect of the operation of Neo-synthecism. The above discussion only points in a direction: it shows very basically how Neo-synthecism can be used as a tool for interpretation and understanding of the past; eventually we will come to see the possibilities for interpreting the future as history. Consideration must first be given to some further 
basic attributes of Neo-synthecism.

Rightly or wrongly, intellectual historians tend to look upon history as an act of cognitive involvement; one in which ideas tend to prevail over mere activity. Certainly this is at least in part true. Neo-synthecism is, to a great extent, the verification of this idea. On the one hand it accounts for human cognition in terms of directed activity; on the other hand, it does not deny economic, psychosexual, religious (or whatever) theories of historical causation. It merely places them within the context of the self-fulfilling prophecy. This, however, raises a pertinent question: is the self-fulfilling prophecy, in historical situations, only one aspect of a larger subject and, if so, what may that subject be? or is it a larger subject in itself, of which other, hitherto unrelated "fields-in-themselves" are but a part? That it should be introduced by the sociologist, Robert Merton, is, in itself I think, significant. Considering the probability of unconscious motivation it would seem more properly within the realm of the psychologist. Yet we find the major, definitive work done in a sociological context. At this particular juncture I wish to only raise the point -- not explain it. There is reason, however, to raise the question of the psychologist's involvement, as well as that of the sociologist and historian, in the exploration of this important but neglected subject.

It seems almost inconceivable, on reflection, that human existence could be considered "in toto" without benefit of an adequate understanding of the operation of the self-fulfilling prophecy. Perhaps the closest, and only, approach outside of Merton to the idea 
comes from Existential philosophy. Sartre's "project," for example, (i.e. conscious commitment to a course of action) probably touches more than Sartre himself realized, in his discussions on psychology, the deepest elements of human culture and civilization. ${ }^{13}$

Further the concept of the self-fulfilling prophecy is, in part, dependent on whether or not it is possible to determine a "national character," or at least leaders of a certain viewpoint. David $M$. Potter in his book People of Plenty raises and explores the question of the American national character. At the same time Potter makes some implicit assumptions concerning the self-fulfilling prophecy which are helpful in understanding Neo-synthecism.

Potter points out that, "...national character is a changing and not a fixed quality, for culture itself.changes"; and culture, "...acting upon and shaping the personality..." is the determinant. 14 Potter derives this conclusion from a study of the work of several social psychologists, sociologists, and anthropologists. He describes how they have investigated the national character, showing the relative rather than the absolute nature of character which is none-theless a real and, verifiable quality. 15

Derivation of national character, then, is a composite of many different approaches, all of which Potter attempts to unify within an historical context. But what is. the national American character? Basically it is a conmitment to a utilization of economic abundance. ${ }^{16}$ As a result of this commitment many things make themselves apparent: individualism, consumer orientation, and some of the persisting social il1s. Potter's views concerning the nature of the American character 
need not be our major concern here. But it is important that Potter feels it possible to define national character; that it is not a static quality; and, finally, that he has come to grips with the problem in a way which precludes any mystical qualifications. But Potter's reliance is not on a simple subjective and unverifiable personal basis. He qualifies his observations in terms of the important work done along the same lines in the behavioral sciences:

The behavioral sciences attach importance to the individual's image of himself, and the group's image of itself, as forces in the formation of character, for the individual or the group will tend to be in fact what they imagine themselves to be in fancy. 17

Potter thus recognizes and attaches no little importance to this veroion of the self-fulfilling prophecy. Throughout his work there remains an Implicit, if not at times explicit assumption that men can shape their future if they are aware of the nature of their goals. Certainly, Potter has opened up the concept of national character to more critical study. Too, he provides us with some of the first valid studies of an extremely difficult problem.

The self-fulfilling prophecy does not in an historical context, however, mean that only one view of the future is required or necessary; in fact, often many prophecies may be made over an extended period of time, and as the terms of one, or several, prophecies are fulfilled, others take their place. Examples abound in American history. For our purposes, however, we will first examine, in Iimited detail, Albert $\mathrm{K}$. Weinberg's Manifest Destiny, a study of nationalist expansionism in American history. 18

The philosophy of manifest destiny as Weinberg defines it is 
"...the doctrine that one nation has a preeminent social worth, a distinctively lofty mission, and consequently unique rights in the application of moral principles." 19 Weinberg's entire effort is directed at showing hos this conception of America's role in the world has shaped its attitudes toward itself as well as its neighbors.

Manifest destiny was in vogue long before the term itself met with public approval, and was coined by John L. O'Sullivan in 1845 in justification of the acquisition of the Oregon territories. ${ }^{20}$ Weinberg describes in detail the many justificatory arguments used to promote expansion, such as Natural Right, Geographical Predestination, the Destined Use of the Soil, Natural Growth, the Extension of Freedom, the White Man's Burden, the Mission of Regeneration, Political Gravitation, Inevitable Destiny, Paramount Interest, Political Affinity, Self Defense, International Police Power, and World Leadership. He illustrates graphically how the contents of manifest destiny have remained consistently the same while the labels and rhetoric have shifted. An analysis of two of Weinberg's chapters will suffice to show his method. By the $1840^{\prime}$ 's manifest destiny had become a by-word in American life. The idea of expansion over the limits of the entire continent was widespread. 21 The scope of expansion, however, was not as important as the assumed superiority of American institutions. More than anything the idea of freedom seemed to most Americans manifestly destined to spread its benefits across the continent. ${ }^{22}$ Weinberg discusses why the idea had not occurred (as one would assume it should have) before this period. Basically the acquisition of the territory did not initially seem necessary. Although, as Federalist paper 
number nine points out, size assures a certain immunity to faction, the area held in mind was only the original 13 states. Another widely held "reason" against expansion previous to the Forties was that it would "endanger the rights and liberites of [both $\mid$ individual states"; and individual citizens. ${ }^{23}$ Fear rather than altruism seems to have initially postponed expansion and prevented such consideration until these fears were dissipated or allayed by the Thirties. Democracy was at last seen as fitting fully into the context of a large geographical area. ${ }^{24}$ None of these effects, however, reasons Weinberg, were enough to explain the outburst of expansionism in the Forties. The cause ultimately lay in a, "...defensive effort to forestall the encroachment of Europe in North America." 25 Thus "extension of the area of 'freedom' was the defiant answer to the extension of European/'absolutism."'26 Weinberg goes on to point out that, significantly, although the United States feared European encroachment, that encroachment was itself caused by a European fear of the growing political and economic power of the Americans. 27 This fear of growing American power, and the resulting "encroachment," explains why the United States had not, previous to 1840 , been as concerned with the generation of absolutism from those quarters.

Three principle grounds are indicated by Weinberg for the American fear of the European menace to her democracy. First, the belief that a direct threat to her security carried with it a direct threat to her political principles. Second, that European absolutism would "pollute" American democracy by its very contiguity. And third and perhaps most influential, that adjacent European expansion would threaten the extension of American democracy. 28 The direct "menace" lay in 
Texas and Oregon. The Union was now seen as imperiled by the failure to annex Texas; too, expansion was seen as a guarantee of states and individuals' rights, and a guarantee against the centralization of federal power. 29 Strangely, as Weinberg indicates, protection was now felt necessary, in certain quarters, against the their own Federal government! 30 Added to these indications were the positive values of individualism through a now espoused pioneering spirit. Thus was born an irresistible march of settlers who believed themselves to be spreading the idea of freedom as they went. The propagation of freedom had become nationalized. 31

Amazingly, the fact that the Texas government was already RepubIican was either ignored or by-passed in arguments for annexation due to the very nature of "nationalized American. freedom." 32 "Impatience" with other men who did not understand the benefits of American freedom moved Americans to exert an example by "pedagogical" methods. 33 It was now put to the American pioneer to go into adjacent areas and spread the idea of American freedom by direct word and action.

Once more, however, directions shifted and the peoples of other non-American nations in our hemisphere, such as Mexico, Republican though they may have been, were seen as bearing the shackles of oppression and needful of the benefits of American freedom. While this a1truism was at least partially felt, the emphasis lay actually on the extension of freedom to; and for, basically white Americans only. Weinberg comments that an incongruous belief had crept into the American philosophy of democracy: "...the belief that, however equal men might be at birth, Americans had become subsequently a super-people."14 
And further, that: "...the 'Forties witnessed the full flowering of national self-esteem in consequence of the undeniable promise in American life, of intensified democratic self-consciousness, of heightened nationalism, and of the partial stupidity of national adolescence." 35 The quality of moral ambition and a national dogma of quasi-heavenly ordained mission were essentially combined. The American concept was a combination of "Calvinist pride and equalitarianism" which saw not the meek, but the free inheriting the earth. 36

A second major area of concern for Weinberg is his chapter entitled "Political Gravitation" which moves from the quasi-moral and ideological themes, of the Thirties and Forties into the quasiscientific and political motives of the Fifties, Sixties, and Seventies.

The new concept of expansion which captured the American mind was based on a notion of physics which sanctioned expansion as an occurrence derived out of the laws of the natural world of inanimate objects and projected into the human political world. Thus the conclusion was drawn, "...that adjacent nations within the range of America's attraction would fall to the Union by a process as inevitable as that causing the ripe apple to fall to earth." ${ }^{37}$ This curious doctrine carried with it more expectations and "more exalted moral sentiment..." 38 than any doctrine of expansion in American history. Weinberg traces the genealogy of Newtonian physics from its application in the sphere of social behavior during the French and American revolutions (where incidentally, in the latter case it was used as a justificatory argument), into international relations, the early 
Canadian annexation schemes, and down to the Cuban "problem" of the middle and late 1850's. It was during the Cuban affair that the term "political gravitation" first came into wide American usage. 39

Why the concept came to fruition only after the Civil War, however, is probably due, as Weinberg comments, to: "...the fertile soil supplied in America itself by the needs which unconsciously form the nationalist's pragmatic criterion of truth."40 This "fertile soil" lay in the intense anti-imperialism of certain Republican leaders, due itself in part to a certain war weariness.'. Furthermore, idealism, emotional nationalism, and strategic, political, and comercial interests, al1 "allied" in a somewhat shaky fashion to promote the idea of "political gravitation". This "political Newtonianism" had several corollaries. First, that an "...analysis of many of the predictions of the believers in political gravitation reveals...the explicit or Implicit assumption of a geographical law". 42 Thus, adjacent islands such as Cuba and the West Indies were seen as geographically destined to "fall" into the waiting arms of America. This in turn was due to the proximity of a large country to a small one. Still another corollary was the "economico-political law of gravitation." 43 Thus economic considerations had found their way into the political sphere. For, it was reasoned, a country economically dependent upon another (as the West Indies, Cuba, and Hawaii were seen to be upon the United States) would be politically drawn into the former's political life. This theory, however, soon applied not only to islands, but also to any contiguous territory. 44 . Weinberg goes on to illustrate how the doctrine was used in justifying the acquisition of Alaska (a neat feat of 
reasoning in itself, considering it was purchased by Secretary of state Seward, and not taken by right!) and for the addition of other territories. But, significantly, when "apples" such as the Dominican RepubIic and Denmark's Carribean possessions were offered the United States, the "law" failed to operate. Weinberg explains this anomaly by the still fresh concern for the problems raised by the Civil War in the late Sixties and early Seventies. Ardent nationalists such as Senator William M. Stewart and Representative Henry R. Gibson explained this condition by projecting the real test of the doctrine into the distant future. $^{45}$ Weinberg also attributes its lack of success to a mistaken political assumption of the transferability by analogy. of "natural law" into human events. Thus two levels of phenomena were discussed as if they were on one level. Further, perhaps one of the most important reasons for failure, outside of the simple fact of the expansionists being in the minority, was, "...the attitude of lesser nationalities toward the greater." For example, the relationship between Spain and its revolting Latin-American colonies, and to "El Colosso" (the United States) to the North. ${ }^{46}$ Americans, strong in nationalism failed to recognize the strength of nationalism in other peoples of other nations. In contradiction to the implied policy of "non-action" that underlay the theory of politiaal gravitation, certain incidents tended to reveal a very active policy. Among the many direct actions, the American interference in Dominican affairs during the Grand administration, marks the high' point of such activity. The ultimate failure of the non-interventionist annexation policy, characterized by political gravitation, Weinberg concludes, was due to: "...the aggressive spirit of 
manifest destiny itself. . it/disposed American's very little to that patient self-possession which was regarded by the stoics as the true lesson of cosmic processes for men." 17

Now that we have seen, to some extent, Weinberg's method in the preceeding examples we must resolve the extent to which the Neo-synthetic theory is applied, and implied, in his study. In itself, the work is an exercise in the process of the unfolding of the self-fulfilling prophecy in American history. Taking Weinberg's definition of manifest destiny as a "jumping off" point will help to illustrate some very basic aspects of his implicit and unspoken assumption of the workings of the self-fulfilling prophecy. Recalling that his definition of manifest destiny was, "...the doctrine that one nation has a preeminent social worth, a distinctively lofty mission, and consequently unique rights in the application of moral principles," ${ }^{48}$ it can be seen that there is a philosophy, or concept, of nationhood which is defined in terms of mission, purpose, and rights. The implications of this definition lie on two levels: first, it is an historian's concept of how a particular people viewed themselves; second, it is not only a definition, but a reality of outlook. That is, it not only relates to an historian's view of a particular people, but also to their own view of themselves. In the latter sense it is a definition concerning a society and its role with regard to itself and its relation to the world around it. But exactly to what extent can it be taken as a valid definition? Certainly, insofar as we know at present, the Deity did not come to earth and voice to some American Moses his projected role for the future of this country. It is also evident that Americans perceived that they alone defined their social 
worth. Nor can it be said that any unique rights were given Americans by God or world opinion. The definitions of America's role, her rights, destiny, mission, and social worth, were determined by her own citizens. Whatever the method of argument utilized, the fact remains that a definition of a problem, role, idea, or whatever, hinges on a prediction made in conjunction with that definition. The function of any such definition is thus to provide a basis of commitment to a concept of action. 49 In doing so, it is important to note that the logic involved in the fulfillment of a prophecy (which is what we shall see such a definition turn out to be) is not as important as the initial prediction itself. Weinberg's arguments, for example those concerning "objective and subjective determinism," implicitly make just such an assumption concerning the role of the irrational. 50 In fact, the bases for his entire study of manifest destiny are founded upon this groundwork. Merton's concept of the self-fulfilling prophecy rests on the idea that, "...in the beginning it is/a false definition of a situation evoking a new behavior which makes the originally false conception come true." 51 Manifest destiny, as Weinberg has illustrated it, is a reflection of Merton's "false definition" being made to come true.

Consider the separate views of the United States and Great Britain with regard to each other in the $1830^{\prime} \mathrm{s}$ and $1840^{\prime} \mathrm{s}$ over the issues of Texas and Oregon territories. The expansionist movements of the Forties, Weinberg has shown, were generated by a growing fear of European encroachment in North America, a fear of the "polluting" influences of Old World absolutism. On the other hand British encroachment was itself, Weinberg contends, caused by a similar fear by Britain of the growing 
political and economic power of the United States. What happened in this case was that the definitions of political, economic, and military motives generated on each party's respective side, evoked new behavior on either's part. This in turn justified and validated what was originally, at least in part, a false belief, thereby evoking further, new behavior. 52 Thus we see the perpetuation of Merton's "reign of terror." 53

As Weinberg points out, there is often a difference' between the attribution and the reality of a cause. For instance there is the problem of whether manifest destiny was directly "caused" by sectional interest (e.g. slaveholders) or whether it found its raison d'etre in an emotional idealism. 54 Therefore, it is necessary to distinguish in all cases the necessary and the sufficient, and to determine what may be considered "relevant cause" from what is an irrelevancy.

The grounds for American fear of European encroachment, in themselves, were not, in the full sense of the word, "real" threats. Rather they were the expression of American fears for what could become the case. Belief that a direct threat to security carried with it a direct threat to political principles may have been well founded. But we have seen that the generation of fears on either side was due to a mutual and reciprocating sense of suspicion. There was, in other words, a feedback effect in which an initial fear generated its opposite, which again in turn reinforced the initial suspicion, and so on, ad infinitum. Certain elements of this primary fear, however, broke away to form their own manner of vicious circularity. Fear of "political pollution", and the threatened curtailing of the extension of American democracy became 
generators on their own behalf. We see here a kind of double-sided effect of the basic Thomas theorem. Whether or not the suspected fear of Britain was true or not, American's defined the situation as real. The same was also true on Britain's part. Both situations were defined situations. Both became eminently real in their consequences. There is, then, a point at which the attribution of a cause, and the reality of a cause become enmeshed and inseparable. Rhetoric, as a guage of sectional interest, for instance was swept up in its own emotional verbage and became, as in the case of Constitutional rhetoric, at once cause and effect. Prophecies generated out of fear, however, are not positive pictures of the future. They present a view of the failure which projects unhappy consequences and conditions. We have seen how Weinberg portrayed the dire consequences predicted by advocating the annexation of Texas. They very structure and cohesiveness of the Union was seen as imperiled by a failure to act in time on the Texas issue. Fear over a loss of individual and states rights was another aid to those prophesizing doom. But what is the real meaning of this kind of prophecy of doom? Essentially, as a careful reading of Weinberg illustrates, such predictions are antithetic images of the future, projected in the attempt to realize a conscious, or unconscious, wished-for "true" image. Instances abound of this negative form of the self-fulfilling prophecy. It is, in fact, a fairly comon form of 20th century "right" and "left" wing political technique. The John Birch Society, in its efforts to "alert" the American people to the menace of internal Communist subversion, continually portrays a future America cowed by its enemies, its ideals perverted, and its people enslaved and degraded. All this effort 
is, of course, not directed at fulfilling this prophecy, but at insuring. its antithetic image.

The Left wing (as well as in some cases the center political groupings) projects a similar gloomy picture, but from a different viewpoint. 55 It tends to view a future of fascist dehumanization with an attendant loss of personal 1iberty. In any case, the attempt is always much the same: as in a photographic process a negative picture is projected in order to insure a positive result.

If this line of reasoning is pursued the question will eventually rise as to why any one view of the future is able to predominate over another. By what process, for example, did a national self-consciousness allow a doctrine such as political gravitation to be given societal sanction? Generally speaking, the self-fulfilling prophecy cannot contradict basic values held by a particular society. For instance, Representative William E. Robinson's confidence, in believing that, "...the time will come when Ireland will be annexed to this country," 56 never came to pass. In addition to the strategic dangers involved in Robinson's statement, traditional American affinity for Britain may have precluded any fulfillment of his prophecy.

Interpretation in terms of the Neo-synthetic theory depends on the degree to which we are able, and agree that historians are in some sense able, to evaluate and embrace the thought and spirit, that is the climate of opinion of another age. The applicability of this generalization, indeed of any historical generalization, demands a certain faith. Weinberg assumes just such a faith in terms of national character when he discusses such subjects as "America's consciousness of national des- 
tiny" 57 and, ". . the assumed superiority of American institutions." 58 There is of course the problem of the masses and leadership: are individuals (presidents, senators, and other public officials) responsible for national opinion; or are the voting masses, responsible? Without attempting to oversimplify a difficult question, the answer probably lies somewhere in between. For while national leaders are responsible for foreign and domestic policy, public opinion may provide at least some impetus to the formation of such policy. The relationship is likely one of a dual reciprocity, heavily weighted on the side of the "elected represenatives." What we call the "state" in the American sense, is supposedly a balance between authority and total liberty (i.e., anarchy). Weinberg and most American historians agree that the "state" is a viable political entity which is responsible for the decisions it makes. Weinberg's discussion of political gravitation is, as it rightly should be, almost entirely in terms of individual statesmen and the "state" itself. While public attitudes may shape policy, ". . . the State. . nevertheless advances through history by means of decisions." 59 The crux of the matter is this: while the argument over who controls the state, the people or the politicians, may be unanswered, the state continues to operate as a discreet unit. Yet any decision the state may make is, in the final analysis, one embodying the essential quality of prophecy. For decisions, such as those of Weinberg writes of with regard to manifest destiny, are commitments based upon expected (or unexpected) reactions. Certainly the conditions of some decisions cannot be fulfilled, as he illustrates in the case of 19 th Century policy toward Latin America and the Carribean. Men often make prophetic statements which never come true. 
Before leaving Weinberg's seminal study, it is necessary to discuss what he calls "the doctrine of inevitability."60 In his discussion he comes very close to a reckoning with the self-fulfilling prophecy:

The general validity of the doctrine of inevitability is of course a question independent of the accuracy of specific predictions. In raising this question of validity one can also leave outside the discussion the broad philosophical question of determinism itself. Determinism holds merely that the will lies within the chain of causality. . . But the expansionists went beyond determinism to a non sequiter. It is, as was shown by their predictions, the dogma that one can know the inevitable before it has happened. This however is the dogma of the metaphysician rather than of the empirical scientist. / ivy underlining./Even predictions projecting the findings of past observations must be of tentative character. . . . for ... the difficulty of prediction is greater in the sphere of phenomena which are dependent upon so great a variety of conditions as is the behavior of human groups. 61

He thus concludes: "The truth is that fundamental motives are too many, varied and conflicting to permit foreknowledge of the motive which will actuate the predominant group: "62

Taken at face value this seems to be a somewhat telling argument against Neo-synthecism in general, for it seems to deny knowledge of a climate of opinion. But is it?

In fact it is not: for Weinberg was not aware in 1935 of several factors which have since been derived from research in the behavioral sciences. I am of course speaking of both the Thomas theorem and Merton's self-fulfilling prophecy. But strangely, although he was writing long before Merton, he came very close to identifying the mechanism of the self-fulfilling prophecy when, quoting. Allendy, he wrote: ". . that once impressed upon the unconscious, ' 1 'image-destinée tend activement à sa réalisation'."63 The self-fulfilling prophecy despite Weinberg's contentions is not, however, a doctrine of inevitability. 
It is a behavioral concept which appears quite correct in its assumptions. To be a "doctrine of inevitability" Neo-synthecism, especially as it concerns the self-fulfilling prophecy, would in part have to allow that human events, if not dictated by reason, are at least interpreted in its light. That is, events would follow really one upon the other. In fact one of the traditional major historico-philosophical problems derives itself from the very question of irrationality. ${ }^{64}$ Hitler's "final solution to the Jewish Problem" can in no way, under present moral canons, be considered rational in either the problem it poses or its "solution." Dachau, Auschwitz, and Belsen-Belsen can, in one way, be defined as the ultimate perversion of casuistry: and this too, is a kind of reason! But what can a statement such as this possibly mean? Only that we must come to grips with the problem of irrationality. Neo-synthecism, while not directly explaining the reasons for the irrational in man (this must be left to psychology) does very importantly provide for its direct expression. As it is not a total explanation of history, but rather an explanation of a process in history, it can, unlike other theories, accept the direct role of the irrational. This must not be construed in any way to mean that irrationality is thereby seen as a predominant historical force (although the possibility certainly exists!) or that Neo-synthecism is based purely upon such an assumption. The full import of this will be discussed in the final section. Weinberg is aware of this problem of the irrational when he discusses motive. There is, however, a certain failure on his part, to recognize the distinction betwecin relating the future from the past, the past from the present, and the future from the present, as they relate to 
historical interpretation. This failure is indeed a crucial one. Weinberg acts as if he has subsumed all three modes of interpretation under one heading. The predictability of events is, as Weinberg recognized, ultimately as difficult in the past as in the future. Both the present and the past present the historian with certain quite similar problems. The past, as well as the future, consists of largely unrelated and undiscovered facts. From our vantage point in time, we like to think that both are vastly different modes of the occasion. The future, we say is "unreadable" because it has not "arrived." The future is either continually moving towards us and/or we toward it. The past on the other hand is said to have ceased to exist. We tend to view the past as Anvid of option, while simultaneously considering the future pregnant with possibility. The more "distant" the past the less relevant it seems to become; the "nearer" the future the more relevant. While Weinberg interprets various cross sections of American history as a function of manifest destiny, he seems to deny the ability to derive a prevailing climate of opinion. The expansionists, he contends, "went beyond determinism to a non sequitur." 65 They assumed the ability to predict the inevitable before it happened, "...as was shown by their predictions."66 Putting aside the specifics of their predictions for a moment, however, one fact is clear: no matter what the particular prediction made, the essential quality of their thought was expansion and the extension of territory. As certain different conditions came to bear in each case, predictions were either fulfilled, as in the case of Texas and Oregon, or passed $\mathrm{o}$ oblivion, as with Canada and Ireland. Weinberg has stated that knowledge of the future, even from the vantage 
of the present looking into the past, must be of a "tentative character." Specifically, however, knowledge of the future, (or as Weinberg says, "the inevitable") is the, "dogma of the metaphysician."67 He fails to realize that if one acts as if he knows the future, or the inevitable, he will likely attempt to make his view come to pass. That 1s, he will try to fulfill his own prophecy. Thus, despite the expansionist's logic being a non sequitur. it must have followed in their own minds. Thus, too, they must have shared a "climate of opinion," logical or not. A1though the prediction of human behavior may be difficult, it does not, within limits, seem altogether impossible. Weinberg implicitly accepts, as we have seen in the body of his writing, a certain unity and conformity of opinion. If he did not, the concept of expansionism would be meaningless. His conclusion that "fundamental motives" are too varied and conflicting to predict predominant actuating motives for differing groups, seems, therefore, too hard and fast in its judgment.

Further, Weinberg writes concerning motive interpretation: ...even ability to foretell the victorious motive would not overcome the difficulty offered by another fact... It is that the same motive, in accordance with varying interpretations of an issue, impelled different individuals in opposite directions....68

Yet, if his judgment is correct then his analysis of manifest destiny is only a variety of speculative history. For the historian, from his vantage point in the future, presumes to know at least some of the predominating motives of an event. If this is true, the historian can know neither the future nor the past; Weinberg would not, however, seem to agree to this. For although the subject matter of history lies in the past, the historian must ultimately realize that it can never exist outside of the context of the present and the future. 


\section{CHAPTER IV \\ MYTH, HISTORY, AND THE FÚTURE}

In discussing myth and history it must not be assumed that any new data will be provided or derived as it relates directly to the concept of myth itself. Myth as it is used here refers to, "an illfounded belief held uncritically especially by an interested group."1 In this context the definition becomes not simply a fanciful story of past events and their relation to the formation of man and his world, but also, in the context of Neo-synthecism, an explanation of why certain historical events come to pass. Behind myth we will see, as this analysis progresses, its intimate connection with the self-fulfilling prophecy. The relationship between the two provides a new tool for. understanding what has happened, and what is happening, in history. In this regard Charles L. Sanford, in The Quest for Paradise, has not neglected the import of myth as a causative factor in the unfolding of history. He says for instance, concerning the role of the myth of the Garden of Eden, "It would be difficult to exaggerate the extent to which such mythology has contributed to the dynamism of history." Sanford contends in fact, that the Christian Edenic myth, and its many variations, has been the most powerful and dynamic force in American history: "...myth also contributes to historical change, for people try to behave in conformity to myth pictures which portray, as Ernst Cassire says, a dramatic world -- 'the world of actions, of forces, of 
conflicting powers.' History moves, if it moves at all, in the mass, and mass psychology is peculiarily dependent on myth." ${ }^{3}$ Here Sanford is speaking of exactly the things which are the subject of this essay: the self-fulfilling prophecy and behavioral science as they relate to history and historical process.

Sanford's analysis of the role of the edenic myth is, thus, a detailed study of the manner in which it has moved through time and space from its origin into the stream of the American life style. He demonstrates, by what he calls the "Journey Pattern of Modern History," how the vision of a heavenly paradise was transformed into an idea of an earthly view of the future. ${ }^{4}$ With the discovery of the New World the medieval mind was finally opened to the possibilities of the fulfillment of the image of a worldly paradise which lay somewhere in the West. Columbus, for example, apparently felt that the Biblical injunction to proclaim the gospel to the ends of the earth would, in conjunction with the discovery of a "New World" to the West, fulfill the prophecy of Christ's second coming. 5 Vespucci too, "...felt the Iure of paradise in the trade winds off South America." 6 Thus, at least part of the impetus for exploring and settling the New World lay in the idea of an image of paradise on earth. But beyond this urge to locate earthly paradise in the West lay other considerations for exploration. The English, for example, considered themselves, "... divinely appointed to establish themselves in the promised lands of the New World!" 7 Following the sun in its westward course the Puritans as representatives of just such a "divine appointment," "...believed on the whole, that they were the chosen instruments to set up a 
city on the hill' as an example of the true Reformation to Europe and the rest of the world. In this mission they regarded themselves as the heirs of all history, curiously unappreciated by Englishmen at home, for whose salvation they prayed." 8 It is this self-characterization of themselves as the "heirs of all history" that makes Americans regard their civilization and culture as a chosen one. The United States, Sanford contends, embodies more than any other nation, an attempt to realize a perfect Protestant reformation in an earthly paradise. 9 It is this spixit of Protestantism which has come to predominantly characterize Americans: "Protestants were assuredly not people to whom things happened, but people who made things happen, and they tried to make them happen according to a divine plan operative in history."10 This regard for the working of historical forces, plus a much vaunted spirit of individualism based in material wealth, accounts for much of the success which Americans have had in turning history (until of late) to their own purposes. In other words, Americans have tended to define and shape their own future as they saw it. Sanford remarks, quite significantly, that as regards the early period of the Continent's settling, the probability is that, "...historians have underestimated seriously the extent to which millenial fervor molded the motives of colonists, gave them their objectives, and controlled their conduct." 11 America, Sanford seems to contend, was born with a spirit of literal self-determination, yet divinely appointed and to some extent determined! The colonists held little doubt that America was to be the site of the second coming. ${ }^{12}$ But before Christ returned, the earth was to be paradisically transformed, "...as an outward symbol 
of $\Gamma_{-}$an/ inward state."13 The "race" for empire which continued until the late 19th century between the New World and the 01d ultimately became one of propagating the gospel, converting the heathen, and assigning paradise to earth so as to insure in each nation the right to call itself "chosen." 14 Weinberg, as we have seen in the previous section, discusses the proseletyzing spirit of the American pioneer: he was to be a missionary of Christianity, economics, and freedom. The primary functions of Weinberg's pioneer become in part; for Sanford, aspects of a broader international spirit. The Spanish and English, for instance, were as interested as the Americans in extending their concepts of religion and government to the New World. 15 But for Americans in particular, "Missionary work on the American frontier contributed greatly to what was to become an American superiority complex; it gave divine sanction to the nineteenth century theme of Manifest Destiny; and it helped to make Americans great proselytizers all over the world of the American Way of Life." 16

From the beginning down to the present the emphasis in the United States has been that Americans are a chosen people who, "...were to usher in the final stage of history."17 American imperialism in the form of manifest destiny, along with the later 20 th century emphasis on political-military isolation, were both the result of a certain spiritual longing. The former was born of optimism and the latter from the disappointments of political realities. 18

Sanford's myth picture and its role extends through all phases of American industrial, political, cultural, and intellectual life. The myth of the garden seems on the surface, however, missing in the late 19th and early 20th centuries. On the contrary, however, the myth 
continues, albeit in somewhat altered form. The role of the myth has become one of a pervasive expectation of reform and progress:

As a result of the covenant promise, Americans collectively have/come to take/for granted a rich inheritance of inward and outward life and have grown accustomed to making extravagant demands upon a radiant future. This Edenic promise that made them inveterate reformers, instruments of optimistic fatalism as well as victims of their own impatience and frustrations.19

Thrust into a world position of prominence, Americans have attempted to bridge the gap of what had become isolationism to internationalism by calling forth her traditional role as moral reformer in a world of sin. 20 Sanford characterizes this as, "the policy of messianic intervention." 21 The policy thereby generated, of reading world politics as a "gigantic conspiracy of satanic forces arrayed against the children of God," 22 has led America into frustration and disappointment. Its failure to be consistently victorious, to gain support and sympathy, has led, Sanford concludes, to a call for moral regeneration at the expense of keeping touch with reality. What may now be finally happening is that Americans are coming to realize that they may have been dispossessed from Eden. 23

Sanford's interpretation rests on the dynamic role of myth in historical causation. Thus he displays the manner by which a nation has tried, and in many instances succeeded, in calling an image of the future into reality. The myth he speaks of is not, in the final analysis, really myth as such; it is simply a view of the future, as any such myth must be. What Sanford succeeds in doing, however, is to show how myths must, in the face of the real world, come to terms with the possible and with other myth pictures. The traditional American view 
of moral regeneration and spiritual re-birth out of a "European hell" must finally come to grips with the explosive awakening of a world of "under-developed" nations, each with their own view of what the future must hold. The problem Sanford implicitly raises is one of priorities: which view of the future is to take precedence over another; the American's or the under-developed nations'. This in turn raises a further problem: is it possible for one nation's view of the future to predominate over all other nations particular pictures? Weinberg partially answered this question in the negative. But Sanford feels it necessary for Americans to review their view in terms of the world we must live in and with. Neither writer, however, really comes to close grips with the problem. Perhaps the most specific approach to this problem has been made by Robert I. Heilbroner in The Future as History. Heilbroner displays, with rare perspicasity, how Americans have tended to look upon the future as history. In other words how, "...we have approached the future with the sustaining beliefs of a philosophy of optimism. That is, we have always conceived of the future in terms of its benignity, its malleability, its compatability with our hopes and desires."24 This philosophy of optimism is, "at bottom, ... an historic attitude toward the future -- an attitude based on the tacit premise that the future will accommodate the striving we bring to it..." 25 Once again then, we encounter the idea that man is able to project his concept of the future into reality. Heilbroner finds reason to believe that the day of such conceptual realization has, as far as national and international relations, passed. The past realization of our national goals, both internal and external, he contends, relied 
on the United States's insulated position in a world of contending and conflicting ideologies. Therein lay the secret of America's success in effecting the transferral of its ideals into reality. In the contemporary world, however, the insulation of physical and ideological barriers has been stripped away, projecting America directly into the course of world events. In this uninsulated position the United States finds its own view of the future in direct competition with other views. The rising expectations of the "Third World" countries have, as a result of our conspicuous display of wealth, been increased immeasurably. But the effort to realize these expectations has met with almost universal disappointment. Most nations have neither the inherent wealth nor the time to develop what wealth they may posses, nor the relative freedom from the hegemony of an international system of corporate organization now personified in the United States. The process whereby a particular economic view of the future can be realized has traditionally been for Americans one based upon "capitalism" and "individualism". The basic conflict which faces America is between the extension of its economic system, based on wealth and time, on relative freedom from international exploitation (which existed in the early history of the United States), and the realities of a world which has neither. The failure to realize that other countries do not have the inherent economic background to develop politically along United States style democratic lines leaves America running against ideological time and tide. Heilbroner sees the world's future tied in with direct national planning, what we tend to call socialism. Although Heilbroner does not see the future as inevitably tending in one direction, he 
does see certain lines of development running counter to traditional American standards. 26 Thus, the under-developed nations will tend more toward planned economy and less to free market enterprise; too, as expectations grow and the realization that many of those same expectations cannot be quickly met, national frustration is likely to set in. This frustration will likely, as is in some cases now true, be vented and directed against America. ${ }^{27}$ This means also that America will be faced with national frustration as other nations display motives and policies which seemingly run counter to our own. (After the "fall" of China in 1949 this is exactly what happened. The reaction of the "McCarthyites" was the personification of just such a national frustration.) What this becomes is nothing less than a clash of national prophecy: will the American view of the future prevail or will another view succeed against it? It has been noted earlier that when two or more views of the future come in conflict, the one which shares the general climate of opinion will likely prevail. Heilbroner seems to concur when he says: "As a capitalist nation we are no longer riding with the global tides of economic revolution, but against them." 28 While Heilbroner sees, "the forces of history closing in"29 on America, he does not fall prey to a feeling of inevitability. For while the options open to America may have become more restricted, they have by no means disappeared. He says explicitly that, "...there are no fixed limits to what is historically possible. Rather, different organizations of society define for themselves and the limits of what is and what is not within reach of conscious history-making choice." 30 Heilbroner appears to believe, within limits, the basic validity of the self-fulfilling prophecy. He also suggests another 
facet of the role of myth in historical forces beyond that of which Sanford writes.

In an article entitled "Myth in the East-West Conflict," 31 John H. Kautsky raises the direct problem of the role of myth in shaping and directing national policy both here and abroad. In this article, which incidentally first led me to the concept of the self-fulfilling prophecy in history, Kautsky discusses the various labels which lead to inappropriate symbol transference and usage. "Socialist," for example, is, as Kautsky notes, hardly an appropriate term for an African leader who, "...represents intellectuals aiming at rapid industrialization rather than workers aiming at improving their position in an already industrialized society..." ${ }^{32}$ The question of labels, while not entirely neglected by Heilbroner, is somewhat glossed over. Kautsky on the other hand gives it the needed emphasis. Basing his concept of myth on George Sorel's definition of myths, as "a complex of remote goals, tense moral moods and expectations of apolyptic success," 33 Kautsky demonstrates how such concepts as Marxism, Communism, American democracy, etc., are all based on industrialized societies whose method for goal attainment is often irrelevant to the goals of an aspiring underdeveloped country." "Thus," writes Kautsky, "Western ideologies, which in their own environment can have at least some realistic programatic content, become myths in the Sorelian sense in their new underdeveloped environment." 34 The real problem is that having become attached to the particular meanings of such concepts as "democracy" and "socialism" in the context of their own particular situation, people continue to react to new uses of the terms in old contexts. Revolu- 
tionary movements which couch their purpose in terms such as

"democracy" against "tyranny" often at first find ample Western support albeit their true nature is lost on the Western political mind. Cuba is perhaps the best representative of this type.

Kautsky goes on to describe how Soviet Marxism is, in its turn, ultimately a creation of myth. He says, concerning this characterization,

What needs to be stressed....is...that the Marxian categories, which are clearly misapplied to the Bolsheviks' actions as explanatory or descriptive concepts, became myths that have affected behavior. The Communists' broad program of industrialization as actually followed, especially by Stalin, would quite probably have been followed by other modernizing revolutionary intellectuals even if they had never heard of Marx. 35

Similarly, Kautsky examines the effects of myth in foreign rela-

tions between the United States and the Soviet Union.

Pointing to the realization on Lenin's part that the Soviet revolution of 1917 did not, as Marx said it would, take place in an industrial nation, Kautsky traces the genesis of fear and mutual distrust built up between the United States and the Soviet Union over the past 50 years. 36 Much of this fear, Kautsky concludes, "... has been due to the mistaken belief on both sides, that it was a revolution appropriate to an advanced country, a revolution of a proletariat against capitalism." 37 The myth of world communist revolution still of course generates fear among the political leaders of the "West," as does fear of capitalist-imperialism among those of the "East." Growing economic power has led the Soviet Union to "play down" this latter aspect, so prominent in its foreign policy when it was weak. (Due in part, also, to the American intervention in the Russian civil war of 1919-1920.) Now that the 
Soviet Union has become strong militarily as well as industrially it can rely on the more esoteric forms in the fight against "Imperialism." As Kautsky notes: "the realization of World Communism has been postponed to the dim future. 138

Kautsky goes on to discuss the implications of symbols as instruments of reassurance and as self-perpetuating quantities. What is important here, however, and what Kautsky does not discuss directly, is how myth may ultimately cause war. The pattern is actually a fairly simple one: because of the myths perpetuated by both the United States and the Soviet Inion, a mutual mistrust has arisen. (The actual reasons behind the myths do not matter, only the result.) Each arms in fear of the other's intentions. Each sees the other's growing military might, and each grows more apprehensive. As the armaments grow, suspicion that the other wants war and intends to wage it, grows accordingly. Finally each expects war as inevitable, causing it to, of course, finally break into the open. That the United States and the Soviet Union operate on such an assumption is clearly the case. The so-called military-industrial complex which $C$. Wright Mills described so perceptively in The Power Elite ${ }^{39}$ is the direct result of just such a military-political myth picture. Perhaps no better illustration could be made to point out the relevancy of the self-fulfilling prophecy in historical-political situations. Ultimately, such prophecy coming to fulfillment could mean the end, not only of civilization, but of man and even of all life itself. Although the future of man is doubtless important, the understanding of what makes man act in history is, in the immediate present, far more relevant to civilization. The future 
in one sense depends not on what man may do, but what motivates him and how it motivates him. If we do not learn to fully comprehend the mechanism of historical activity we may never live to contemplate what a lack of understanding may mean. 


\section{CHAPTER V}

\section{IMPLICATIONS}

History, we are told, is what has happened. No one it seems, however, ever makes it quite clear how the relating of this is to be done. On the one hand there are Relativistic, Idealistic, Heroic, Dialectic, Materialistic, Eschatological, Chiliastic, Positivistic and like theories of explanation. On the other there is, for instance, the sceptic denying our ability to know anything about our past, or the "ahistoric" individual simply dismissing it all as irrelevant in any case. While an "ahistoric" attitude has a certain simplicity which is appealing it does not seem to satisfy intellectual curiousity (if such can ever be possible). But historians are, if not driven to seek cause in history, fascinated by the prospects such a possibility carries. History is, at base, probably relevant to man because he is searching for patterns in the past which will guarantee his future. George Santayana has said, in a famous quotation, that he who does not study history is doomed to repeat it. In so far as man believes such a statement he believes in progress. When a problem is no longer relevant man will no longer look to the past for information concerning its elimination. When a belief in progress is no longer relevant, man will, in all likelihood, no longer look to history for direction. While Heilbroner may feel that the very concept of progress is somehow doomed to decline in importance and perhaps wither away altogether, 
it is likely that history will continue to maintain a certain relevance for man. Heilbroner has said that a philosophy of optimism requires a certain attitude which may be called almost exclusively American. ${ }^{1}$ The prospect arises that only in a progress-oriented society can Neo-synthecism be fully and completely operative. If society does advance through history by conscious decisions, then a static culture would seemingly not be as prone to make decisions about the particular shape of things to come. Such a society would perhaps be content to "rest upon its laurels," and not consciously choose truly specific courses of action. In the long run, a nation's political fortunes probably depend upon great national wealth and an explosive surge of creative and innovative talent to put such wealth to use. ${ }^{2}$ Alone, neither would seem to be sufficient. America, almost uniquely among modern nations, has been blessed with both to the extent that it has experienced an incredible technological "jump" unsurpassed in all past time. The material wealth of the United States has, in part, made it possible for Americans to believe in a bountiful and beneficent future. But such hope is based for the most part on a beneficent past. There is thus the concept of progress as an interdependency between the "reality" of what has happened and what the future holds as possibilities. If the past is held as relevant, so will be the future.

Today, however, historical interpretation, if not history itself, has become increasingly complex. Simplistic notions of progress will no longer suffice. To understand what has happened in history, historians of the future will be faced with accepting the behavioral sciences as a tool for more complete comprehension. Perhaps the most 
frustrating mistake historians can make is to view such a complex creature as man as if he were a simple, easily definable and recognizable quantity. History, if it is anything is not simply a record of what has happened, but rather what has happened to man. As man is incredibly complex, so, too, history is similarly complex. The other primary mistake of the historian is to approach history as if it were simply a recording of the events which have transpired among men; not as if it were an intricate, delicately balanced network of human action and interaction, based on the vagaries of emotion and the web of the intellect. Most historians probably realize the role of interpretation. What many neglect is an adequate understanding of just what it is they are interpreting: man. To attempt the writing of history in such circumstance is not unlike trying to predict the path of a ballistic missile without knowing how such a missile works, or what it is for. It can be done, but of what relevance is it if one does not know what such a missile is meant to do? It is a case of too little too late. Few will probably deny the important role of the behavioral sciences as an historical tool in some limited degree. But we must ask, what can the behavioral sciences tell us of the outcome of history? Can we really, after all, control it directly? These are the truly crucial questions that must be answered; and the answers are not easy ones.

In reality the behavioral sciences can probably, by themselves, tell us nothing of the outcome of history. They can tell us something of the mechanisms by which history takes place. The understanding of mechanisms can in turn lead us to, if not a general picture of the outcome of history, then perhaps more short run and specialized views. 
An analogy (dangerous as this form of reasoning may be) may help to illustrate this statement. Science knows that certain atomic and subatomic particles behave in a certain way under certain conditions. The ability to predict what a particle will do under certain conditions allows scientists to predict what the outcome of say, a chemical reaction, will be. On the other hand this predictability is in reality a fairly limited kind of activity. To this extent scientists cannot, for example, track a series of particles and make projections for their fate thro ghout all time. Indeed, if this were possible scientists could conceivably start from the present, tracing the paths of particles back through time to their primordial besinnings, then project forward into the future what the fate of all matter will be. Thus they could "read-out" a pre-programmed pattern of the universe, telling us what will happen and when. This would, of course, make everything inevitable. Several minor difficulties stand in the way of this total comprehension surpassing mere understanding. Scientists find themselves, for instance, unable to track both the position and velocity of a particle simultaneously. This is the famous "Heisenberg Indeterminancy Principle." 3 At the same time the sheer gargantuan size of such a projection (if it were possible to do) staggers the intellect. Consider the programing involved in such a project. With one I.B.M. card for each particle and for each projected path, the number of cards would exceed the total number of particles in the known universe! If cross sampling, that is statistical sampling, were attempted, the number of possibilities would make such a sample utterly meaningless. The upshot of all this digression is that while predictability is applicable in science, it is applicable only over an exceedingly limited range. 
Similarly, behavioral science, at best in its infancy, can make only the most modest kinds of predictions concerning human behavior. Nonetheless, the self-fulfilling prophecy, as representative of the behavioral approach, can make modest historical prediction realizable. More than anything, Neo-synthecism makes it possible to understand history as a direct function of human behavior. It shows how men react to the subjective features of a situation as if they were objective. Thus it gives the historian a more complete understanding of the irrational in history. And in one sense, irrationality is to history what the indeterminancy principle is to physics. By exhibiting the process whereby men concretize the irrational we take into account not so much the psychology of the act as the direct manifestation. In this the historian is much like the scientist: as the latter can track only either the position, or measure the velocity of a particle, so the historian-behavioral scientist can interpret either the act of irrationality or the psychology of the act. But ultimately, the hidden reasons that drive a man to act can only be partially known. We cannot go back into time to directly psychoanalyze an historical figure who has acted irrationally; we can only show how he acts in terms of his reasoning, faulty as it may be. In this respect, however, the historian has a slight edge over the scientist for the historian has a direct, albeit piecemeal, picture of what has happened. To the extent he can "see" what has happened he can track simultaneously both the "position" and "velocity" of an historical figure. He can thus directly view irrationality and rationality concretizing itself. He has a view from the future which allows him to see how things will turn 
out. While far from complete, the historian can interpret the past in a much more comprehensive manner than can a physicist attempting to account for the genealogy of a particle. It is, however, in the operations involving the future, that the historian loses interpretive ground to the physicist. For the latter can make predictions based on what appear to be the highly rational workings of nature, using his own "present" as a stable base, while the former is forced to deal with the more obviously irrational forces of man's intellect, with little apparent bases for understanding. In other words, there is a fine line dividing our understanding of the concrete and relatively obvious past human event from the not so obvious sub-atomic event. But with regard to the future the reverse becomes true, and man becomes the supposedly totally unknown factor. At present, particle physics cannot help man understand the minute interactions and relations which make him function but, perhaps, the future of science holds out this possibility. Where science has made contemporary strides more directly applicable is, as we have seen, in behavioral science.

Can we then come to directly control the future and dictate the outcome? America in the Sixties is a troubled land, troubled by racial conflict, by political assassinations and by foreign difficulties, among other things. One thing has become clear in contemporary American history: we are desperately trying to come to grips with the possibilities of our future. America can probably go in many directions, but it can no longer afford to simply "drift." 4 Its people, its cities, its enemies, will not allow the United States to pursue a course dictated by non-involvement. Most Americans are fully aware of the 
implications of a policy, both external and internal, which does not direct. The new politics of Left, Center, and Right reflect a definite sense of direction for good or for evil. America then, is trying to direct its own history. (Some critics, of the American scene would probably go as far as to say that we sre trying to direct the history of everyone!)

The United States, as well as much of the rest of the world, has learned some unique and increasingly important lessons over the past three decades. The implications of what we have learned are fraught with promise and incredible disaster for man in general. One of these important lessons is this: while it may be correct as President Eisenhower said, that men's hearts cannot be legislated to, it is not only probable; but likely, that by placing legal injunctions against certain forms of behavior, certain other "negative" aspects of behavior can be altered. Thus while men may feel no differently in their hearts, their actions can be suited to purposes beyond them. Every society implicitly recognizes this fact when it makes its laws. What this comes down to is but another form of the self-fulfilling prophecy. A society can thus concretize a legal fiction. This in turn can ultimately alter and shape beliefs. Our society is consciously doing just this in relation to the contemporary racial situation. It is trying to shape and direct how, in a fairly precise way, America will look in the future. The Civil Rights Acts of 1866, 1957, 1960, and 1964, are all attempts to do just this. We are then, in the very process of defining our future as we would will it. Martin Luther King, Jr. in 1962, demonstrated and outlined just what is currently taking place in America and how it is happening: 
There are always those who will argue that legislation, court orders and executive decrees from the Federal covernment are ineffective because they cannot legislate morals. But while it may be true that morality cannot be legislated, behavior can be regulated. The law may not change the heart -. but it can restrain the heartless. It will take education and religion to change bad internal attitudes -- but legislation and court orders can control their external effects. Federal court decrees have, for example, altered transportation patterns and changed social mores -- so that the habits, if not the hearts, of people are being altered every day by Federal action. And these major social changes have a cumulative force conditioning other segments of life. 6

By legislating to men, governments attempt to fulfill not only a prophecy of future stability but the shape of society in general, according to certain preconceived ideas. No society can exist without a certain amount of planning. This process faces several problems, however, dealing directly with the self-fulfilling prophecy. First, as Merton points out:

- . an excensive and as yet imperfectly identified type of social science prediction is confronted with a paradox: if it is made public, the prediction becomes seemingly invalidated and if it is not made public it is generally regarded as postdiction. It is considered knowledge after the fact.7

As social scientists have come to recognize, a prediction, or prophecy, can invalidate itself once the terms come to be fully recognized. Merton illustrates this by pointing, out that a

- . government economist's distant forecase of an oversupply of wheat may possibly lead individual producers of wheat to so curtail their planned production as to invalidate the forecast. 8

Thus, too, as the intent of civil rights legislation comes to be generally known, it can be invalidated by direct resistance, as in the case of militants of either race. This kind of process is called the "selfdestroying belief" by Merton. ${ }^{9}$. It points up the problem of defining and identifying conscious and unconscious prophecy within society. By 
directly identifying and exhibiting such beliefs the social scientist and historian run the risk of negating their discoveries concerning the future of a given society. This problem, however, is of relatively little importance in view of the other major problem social prediction implies. If, as $\mathrm{C}$. Wright Mills contends there is a military, political, and industrial elite which is shaping and guiding American policy here and abroad, ${ }^{10}$ the possibility for direct. social control by a relatively few men certainly exists. Governmental legislation could be aimed at direct population control by extremely subtle and sophisticated means. Thus, a legislative effort could be made directing its attention at unifying white and black in America not simply because it is "right," but because it solidifies the political control of the larger white majority. While such activity could only be subtly directed in America, its studied application in China, for example, is hardly subtle. It would seem in the latter case that social stability was being maintained in part by projecting a view of the future which sees a "jihad", or "holy war", with either the United States or the Soviet Union as possible, if not inevitable. The point is that a view of the future can have very negative implications for control as well as general outcome. The elements of planning for the future, so necessary for society, can be twisted to uses beyond the individual citizen to the advantage of a single group or political figure. George Orwell's 1984 is the perfect picture of what a society can read into its future, horrifying as it may be. Recognition of the problem can obviously help to allay the possibilities of such a prospect by realizing new socially beneficent and sound policy. Neo-synthecism then, can help as a tool for the 
interpretation of the historical past and the probable historical future; to create and most importantly discover and analyze those functions which society takes for granted -- those functions which society implicitly recognizes but often does not speak of consciously. Neo-synthecism is more than a way of looking at history -- ultimately it is a way of describing all the interlocking activities of man. It is thus possible to look upon it as an activity transcending one or two disciplines for an interdisciplinary approach to the ultimate goal of all human activity: the understanding of man and his relation to the universe. Neo-synthecism while not answering the "why" of things in a metaphysical manner, can certainly aim at an explanation in terms of the physical reality of human nature. I do not mean to denigrate the role of the spiritual in the explanation of human events; this must, however, take its place in the non-empirical side of human affairs. It must, therefore, be taken into account, but not as a total explanation. It is but one facet of human activity and, like the irrational, has its own reasons, and must, therefore, be accounted for.

Each man finds his own time the most difficult, the most dangerous, and the most intriguing in history. The perspectives so necessary to a master of oneself and ones times and environment are not easily won by any generation. Some succeed, others fail miserably. Each generation tries its best to cope with the world as it finds it. No generation has ever made the world they inherited; each generation changes the world it finds itself swept into. Events can probably control men -- but men can, if they will but try, control events. History, if it teaches us anything teaches us this fact. There is a point man 
must come to in dealing with history and the currents of contemporary events when he will have to take responsibility for his activity. Irrationality can be no excuse for the course of events, for man is responsible for that very irrationality. We have seen, in a limited way, the manner in which historians and social scientists have come to realize the proper role of man in history. Some, the behavioral scientists for example, exhibit this role explicitly. Historians utilize this generalization, but often unwittingly.

Americans are generally said to be committed to the idea of progress and individualism. What they really have been committed to is action in the pursuit of a particular future. The time has come for a fuller understanding of the process whereby men make history come to pass. It will be a difficult endeavor, for in observing and recording we may alter the outcome we expect. Too, we must take into consideration the nature of change itself. There are obviousty factors we shall never be able to take into account. Who would have accepted one-hundred years ago the real possibilities of a voyage around the moon? Even now the voyages being made into space take on an almost unreal quality. But while it is impossible to account for specific change it is not impossible to be prepared for it. In terms of the historical process, both past and future, the Neo-synthetic theory allows for non-absolute continuity, while providing "relative" and conditional continuity. What this means is that the unexpected need not destroy the efficacy of Neosynthecism. For instance, the past seems static and unchanging to the observer looking "back." Occasionally, however, this static condition reveals a certain unexpected dynamism when a new "fact" comes to light and changes an entire historical perspective. 
Charles A. Beard's An Economic Interpretation of the Constitution is a case in point. 11 suddenly new vistas open up and the past somehow changes. While some people are upset, most exhibit a certain curiousity. But when an expected future event, such as was the case with democracy in Cuba, does not come to pass most people are either very upset or at least must change some of their plans. Unfulfilled expectations can be very disquieting. If we do succeed in making predictions, or at very least, discovering implicit prophecy within society, its non-fulfillment would seem to destroy the predictive capabilities of Neo-synthecism. But if we keep in mind the limits and ranges of our activities in the same manner as a nuclear physicist does, we can allow for sudden and dramatic change. Such change need not upset the historian or behavioral scientist, but rather serve to remind him that a turn in the road of time is indicated and must be accounted for. As the title of this essay suggests, it is necessary for the historian to not only look back upon the past from the perspective of the moment, but to also "look back" from the future, in terms of its possibilities, to discover the real meaning of the present. One must have, in this sense, a "view from the future." History is a discipline that must be approached delicately and perceptively, for so much of it is interpretive. And, as Paul Ricoeur has said, "If we want to be instructed by events, then we must not be in a hurry to solve them."12 
CHAPTER NOTES

Chapter One

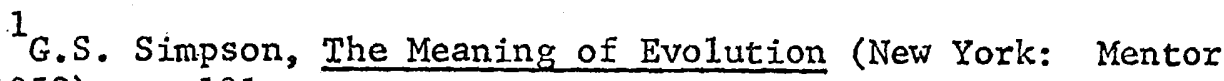
Books, 1952), p. 181.

2R.M. MacIver, Social Causation (New York: Ginn and Co., 1942), p. 133.

Chapter Two

$1_{\text {R.K. Merton, Social Theory and Social Structure (Glencoe, }}$ Illinois: The Free Press, 1957), chapter XI.

${ }^{2}$ Ibid., p. 421. Merton refers here to W.I. Thomas, whom he cal1s "the dean of American sociologists.".

${ }^{3}$ Ibid., pp. 421-422.

${ }^{4}$ Ibid., p. 422 .

5 Ibid. This happened in 1933 when President Roosevelt closed the banks and then reopened them, indicating that the situation was now under control, when in fact nothing had really been done -- it was all a matter of confidence.

6 Ibid., p. 423.

7 Ibid.

Chapter Three

$1_{\text {Robert Heilbroner, The Future As History (New York: Harper }}$ and Row, 1960.

2 Eugene Kamenka, "The Concept of a Political Revolution," in Revolution, ed. by Carl J. Friedrich (New York: Atherton, 1966), p. 122 .

3 Miguel Unamuno, The Tragic Sense of Life (New York: Dover Publications, Inc., 1954), p. 321. 
${ }^{4}$ See for example, Curtis P. Nettles, The Roots of American Civilization (New York: Appleton-Century-Crofts, 1963), especially chapter XXIII, and V. L. Parrington, Main Currents In American Thought, Vol. I, "The Colonial Mind." (New York: Harcourt, Brace and World, 1927).

${ }^{5}$ Leonard Kriega1, ed., Essential Documients of the Founding Fathers (New York: Bantain Books, 1964), p. 190. See also, Carl Becker, The Declaration of Independence (New York: Vintage Books, 1942).

${ }^{6}$ Ibid.

7

Ibid., p. 21 .

8 Ibid., p. 154.

${ }^{9}$ Ibid., p. 462. See also, for example, the Constitutional debates, especially that of 31 May, 1787 over democracy and the lower - house in S.E. Morison, Sources and Documents Illustrating the American Revolution 1764-1788, and the Formation of the Federal Constitution (New York: Oxford University Press, 1965).

${ }^{10}$ Arnold Rose, The Negro In America, the condensed version of Gunnar Myrdals, An American Dilemma (New York: Harper and Row, 1964)

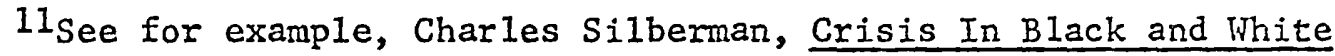
(New York: Random House, 1964).

${ }^{12}$ Leonard Kriegal, ed., Essential Documents...., p. 448.

13 Jean-Paul Sartre, Existentialism and Human Emotions (New York: Philosophical Library, 1957), see especially the section on Existentialist Psychoanalysis.

${ }^{14}$ David M. Potter, People of Plenty (Chicago: The University of Chicago Press, 1968), p. 42.

$$
\begin{aligned}
& 15_{\text {Ibid., p. }} 57 . \\
& 16_{\text {Ibid., p. } 126 .} \\
& 17_{\text {Ibid., p. } 76 .}
\end{aligned}
$$

${ }^{18}$ Albert $K$. Weinberg, Manifest Destiny (Chicago: Quadrangle Books, Inc., 1935).

$$
\begin{aligned}
& { }^{19} \text { Ibid., p. } 8 . \\
& 20_{\text {Ibid. }}, \text { pp. } 111-112 . \\
& 21_{\text {Ibid. }} \text { p. } 100 .
\end{aligned}
$$


22 Ibid., pp. 112-113.

23

Ibid., p. 104.

${ }^{24}$ Ibid., p. 107.

${ }^{25}$ Ibid., p. 109.

${ }^{26}$ Ibid.

27 Ibid., p. 112 .

${ }^{28}$ Ibid.

${ }^{29}$ Ibid., p. 113.

${ }^{30}$ Ibid., p. 114.

${ }^{31}$ Ibid., p. 116.

${ }^{32}$ Ibid., p. 122 .

33

Ibid.

${ }^{34}$ Ibid., p. 126.

${ }^{35_{\text {Ibid. }}}$ p. 127.

${ }^{36}$ Ibid., p. 129.

${ }^{37}$ Ibid., p. 225.

${ }^{38}$ Ibid.

${ }^{39}$ Ibid., p. 230.

40 Ibid., p. 231.

41

Ibid.

42 Ibid., pp. 233-234.

${ }^{43}$ Ibid., p. 238 :

${ }^{44}$ Ibid.

${ }^{45}$ Ibid., p. 245.

46

Ibid., p. 247.

47 Ibid., p. 250.

${ }^{48}$ Ibid., p. 8. 
${ }^{49}$ Weinberg writes, "According to the Latin-American Rodo, the genius of the United States is that of 'force in movement,' or, in a word, imperialism." p. 248.

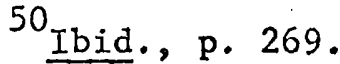

51 Merton, Social Theory and Social Structure, p. 423.

52 Weinberg, Manifest Destiny, p. 101.

53

This may have also been due to a conscious manipulation of fear for the "other" side by men of both sides anxious to provoke conflict for their own ends.

54 Merton, Social Theory and Social Structure, p. 423.

${ }^{55}$ See for example, Frederic C. Jaher, Doubters and Dissenters: Cataclysmic Thought In America, 1885-1918 (New York: The Macmillan Co., 1964). Jaher's book is a combination of perceptive analyses of social problems of the progressive era and the paranoid, neurotic elements involved in the cataclysmic visions of such figures as Henry and Brooks Adams, Jack London, and Homer Lea.

56 Weinberg, Manifest Destiny, p. 242.

57 I bid., p. 100 .

58 Ibid., p. 101.

${ }^{59}$ Ibid., p. 204.

${ }^{60}$ Ibid., p. 280.

$61_{\text {Ibid. }}$

62

Ibid., p. 281.

63 Ibid., p. 280.

${ }^{64}$ See for example, H. Stuart Hughes, History As Art and Science,

(New York: Harper and Row, 1964), chapter III.

65 Weinberg, Manifest Destiny, p. 280.

66

Ibid., p. 280.

67

Ibid.

68

Ibid., p. 281. 
Chapter Four

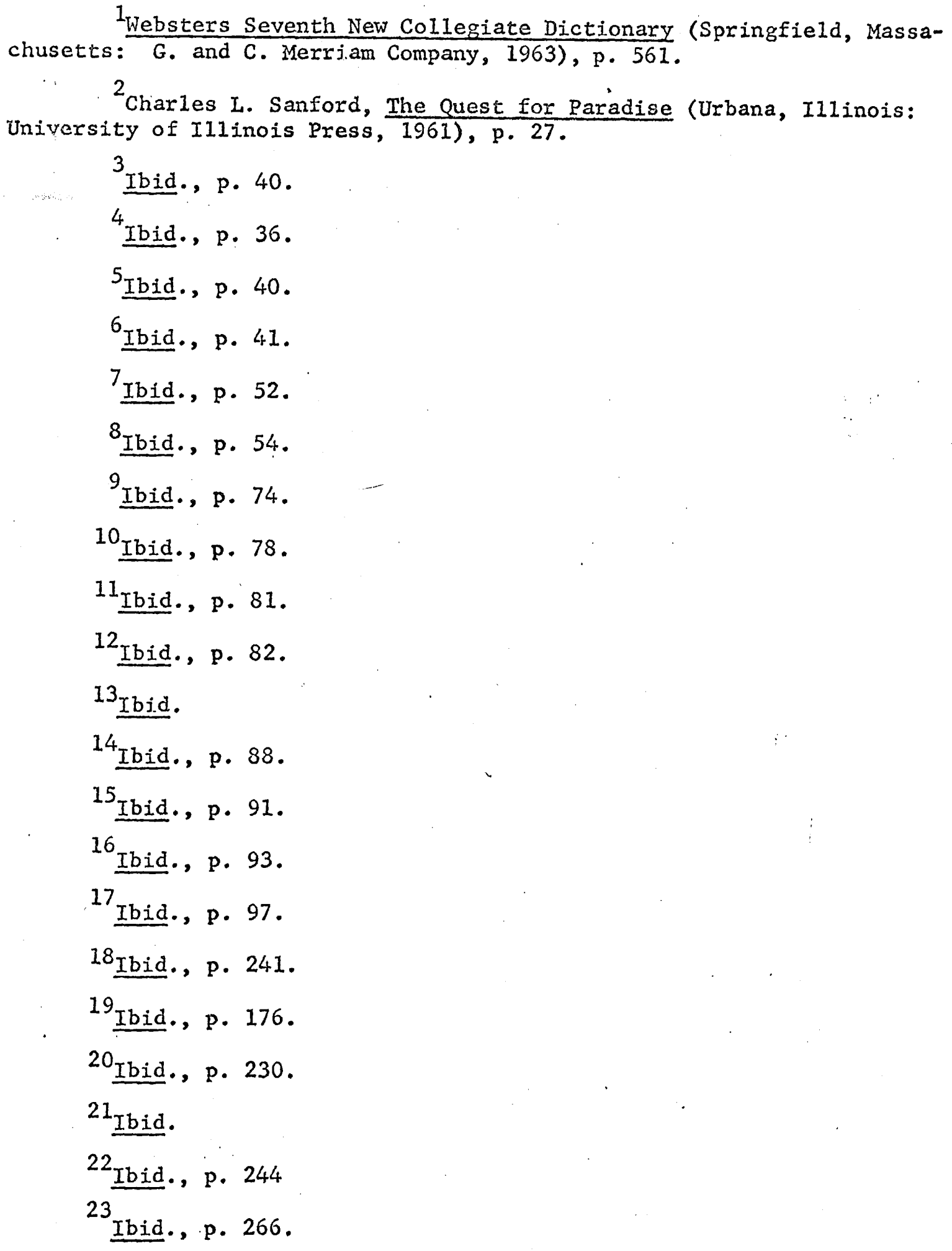

$1_{\text {Websters Seventh New Collegiate Dictionary (Springfield, Massa- }}$ chusetts: G. and C. Merriam Company, 1963), p. 561.

${ }^{2}$ Charles L. Sanford, The Quest for Paradise (Urbana, Illinois: University of IIlinois Press, 1961), p. 27.

${ }^{3}$ Ibid., p. 40 .

4

Ibid., p. 36 .

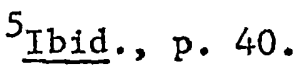

$6_{\text {Ibid., p. } 41 .}$

7 Ibid., p. 52 .

$8_{\text {Ibid., p. } 54 .}$

${ }^{9}$ Ibid., p. 74.

${ }^{10}$ Ibid., p. 78.

${ }^{11_{\text {Ibid. }} \text { p. } 81 .}$

$12_{\text {Ibid., p. } 82 .}$

13 Ibj.d.

${ }^{14}$ Ibid., p. 88.

$15_{\text {Ibid., p. } 91 .}$

${ }^{16}$ Ibid., p. 93.

17 Ibid., p. 97.

${ }^{18}$ Ibid., p. 241.

${ }^{19}$ Ibid., p. 176.

${ }^{20}$ Ibid., p. 230.

${ }^{21}$ Ibid.

22 Ibid., p. 244

23

Ibid., p. 266. 
24 Heilbroner, The Future As History, p. 175.

$25_{\text {Ibid., p. } 17 .}$

${ }^{26}$ Ibid., p. 176 .

27 Ibid.

${ }^{28}$ Ibid., p. 94 .

${ }^{29}$ Ibid., chapter II.

30 Ibid., p. 184.

${ }^{31}$ John H. Kautsky, Communism and the Politics of Development

(New York: John Wiley and Sons, Inc., 1968), chapter VI.

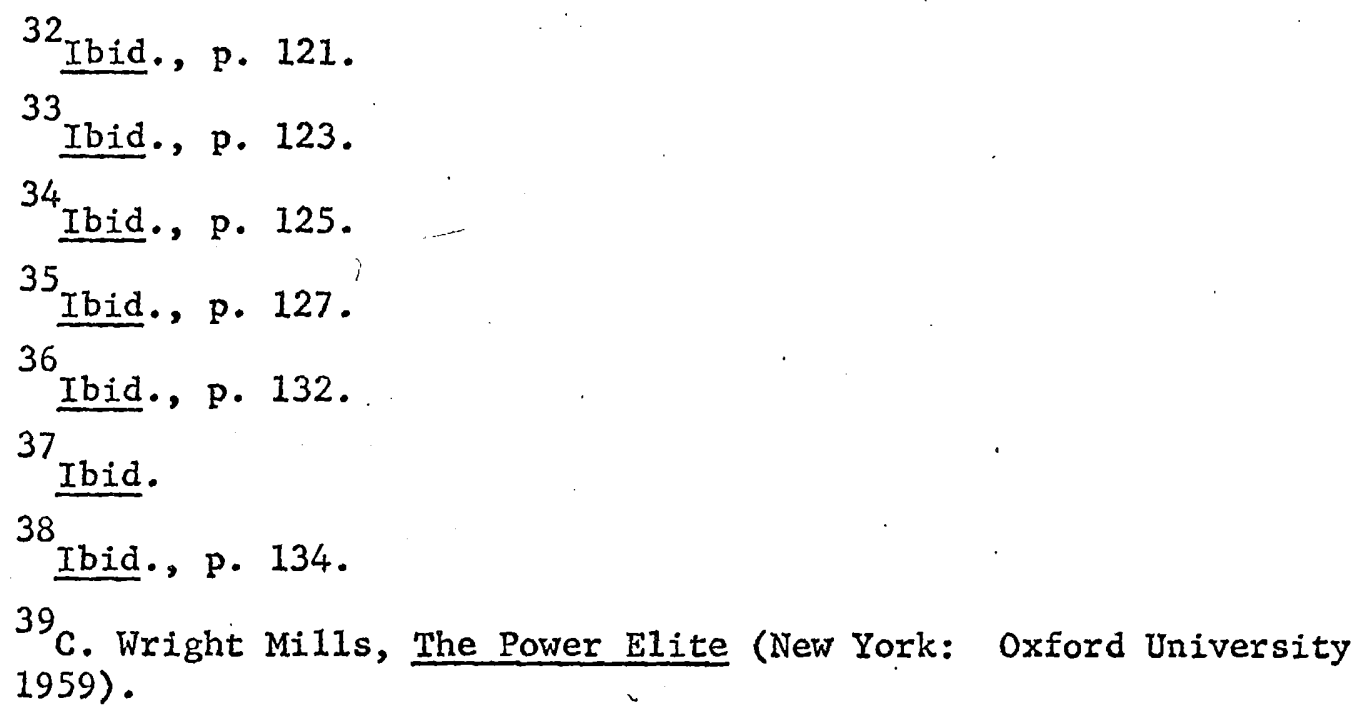

\section{Chapter Five}

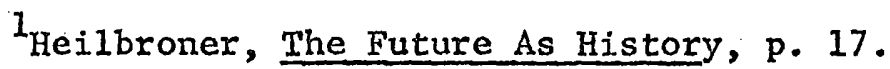

2 Ibid., p. 17 .

${ }^{3}$ See, Werner Heisenberg, Physics and Philosophy (New York: Harper and Row, 1958).

${ }^{4}$ Walter Lippman, Drift and Mastery (New York: M. Kennerley, 1914), remains as applicable in todays world as in 1914.

5 Anthony Lewis and the New York Times, Portrait of A Decade (New York: Bantam Books, 1965), p. 9. 
${ }^{6}$ Ibid., p. 9.

7 Merton, Social Theory and Social Structure, p. 130.

${ }^{8}$ Ibid., p. 129 .

${ }^{9}$ Ibid., p. 130.

10 Mills, The Power Elite.

${ }^{11}$ Charles A. Beard, An Economic Interpretation of the Constitution of the United States (New York: The Macmillan Co., 1913).

12 Paul Ricoeur, History and Truth, trans. by Chas. A. Kelbley (Evanston, Illinois: Northwestern University Press, 1965), p. 247.

\section{Appendix}

$1_{\text {See, Kautsky, Communism and the Politics of Development. }}$

2 Anne Fremantle, ed., Mao Tse-tung: An Anthology of His Writings (New York: Mentor Books, 1962), p. 214.

3 Georgie Anne Geyer, "Why Guevara Failed," Saturday Review August 24, 1968, pp. 14-18.

4 Maurice Merleau-Ponty, Les Aventures De La Dialectique

(Paris: Gallimand, 1955), p. 8 .

${ }^{5}$ Ibid., p. 10. 


\section{BIBLIOGRAPHY}

Bailyn, Bernard, "Political Experience and Enlightenment Ideas in Eighteenth-Century America." American Historical Review, IXVII (January, 1962), 339-51.

Becker, Carl L. The Declaration of Independence. New York: Vintage Books, 1942 .

Beard, Charles A. An Economic Interpretation of the Constitution of the United States. New York: The Macmillan Co., 1913.

Boorstin, Daniel J. The Americans: The Colonial Experience. New York: Random House, Inc., 1958.

Debray Régis. Revolution in the Revolution? Translated by Bobbye Ortiz. New York: Grove Press, Inc., 1967.

Fremantle, Anne, ed. Mao Tse-tung: An Anthology of His Writing. New York: Mentor Books, 1962.

Geyer, Georgie Anne. "Why Guevara Failed." Saturday Review, (August 24, 1968) 14-18.

Greene, Jack P., ed. The Ambiguity of the American Revolution. New York: Harper and Row, Inc., 1968.

Hamilton, Alexander; Madison, James; and Jay, John. The Federalist Papers. Mentor Books. New York: The New American Library, Inc., 1961.

Heer, Friedrich. The Intellectual History of Europe. Vol. II: The Counter Reformation to 1945. New York: Doubleday and Co., Inc., 1965 .

Heilbroner, Robert I. The Future As History. New York: 'Harper and Row, 1960.

Heisenberg, Werner. Physics and Philosophy. New York: Harper and Row, 1958.

Hughes, H. Stuart. History As Art and Science. New York: Harper and Row, 1964.

Jaher, Frederic C. Doubters and Dissenters: Cataclysmic Thought in America, 1885-1918. New York: The Macmillan Co., 1964. 
Kamenka, Eugene. "The Concept of a Political Revolution" in Revolution ed. by Car1 J. Friedrich. New York: Atherton, 1966.

Kautsky, John H. Communism and the Politics of Development. New York: John Wiley and Sons, Inc., 1968.

Kriegal, Leonard, ed. Essential Work. of the Founding Fathers. New York: Bantam Books, 1964.

Lewis, Anthony, and the New York Times. Portrait of A Decade. New York: Bantam Books, 1965.

Lippman, Walter. Drift and Mastery. New York: M. Kennerley, 1914.

Meiland, Jack W. Scepticism and Historical Knowledge. New York: Random House, 1965.

Merleau-Ponty, Maurice. Les Aventures De La Dialectique. Paris: Gallimand, 1955.

Merton, Robert K. Social Theory and Social Structure. Glencoe, Illinois: The Free Press, 1957.

Mills, C. Wright. The Power Elite. New York: Oxford University Press, 1959 .

Morison, S. E., ed. Sources and Documents Illustrating the American Revolution, 1764-1788, and the Formation of the Federa1 Constitution. New York: Oxford University Press, 1965.

Nettles, Curtis P. The Roots of American Civilization. New York: Appelton-Century-Crofts, 1963.

Niebuhr, Reinhold. The Irony of American History. New York: Charles Scribner's Sons, 1952.

Noble, David W. Historians Against History. Minneapolis, Minnesota: The University of Minnesota Press, 1965.

Odajnyk, Walter. Marxism and Existentialism. Garden City, New York: Doubleday and Co., Inc.

Parkes, Henry Bamford. The American Experience. New York: Random House, Inc., 1959.

Parxington, Vernon L. Main Currents In American Thought. Vol. I: "The Colonial Mind," 1620-1800. New York: Harvest Books, 1954.

Potter, David M. People of Plenty. Chicago: The University of Chicago Press, 1968. 
- Ricoeur, Paul. History and Truth. Translated by Charles A. Kelbley Evanston, Illinois: Northwestern University Press, 1965.

Rose, Arnold. The Negro In America. Condensation of Gunnar Myrdal's, An American Dilemna. New York: Harper and Row, 1964.

Sanford, Charles I. The Quest for Paradise. Urbana, Illinois: University of Illinois Press, 1961.

Sartre, Jean-Paul. Existentialism and Human Emotions. New York: The Philosophical Library, 1957.

Silberman, Charles. Crisis in Black and White. New York: Random House, 1964.

Simpson, George Gaylord. The Meaning of Evolution. New York: Mentor Books, 1952.

Smith, H.N. Virgin Land. New York: Alfred A. Knopf, Inc., 1950.

Sydnor, Charles S. American Revolutionaries In the Making. New York: The Free Press, 1965.

Unamuno, Miguel. The Tragic Sense of Life. New York: Dover Publications, Inc., 1954.

Websters Seventh New Collegiate Dictionary. Springfield, Massachusetts: G. and C. Merriam Company, 1963.

Weinberg, Albert K. Manifest Destiny. Chicago: Quadrangle Books, Inc., 1935. 
APPENDIX

There are some relatively obvious connections that can be made between the self-fulfilling prophecy, revolutionary Marxism and revolutionaries in general. As has been noted, every true revolutionary utilizes the self-fulfilling prophecy. Revolutionary Marxism, in its 19 th century orientation toward the evils of industrialism, called for upheaval in those countries which were marked by a high degree of tech'nological, that is industrial, advancement. The standard criticism raised against those so-called "Marxist revolutions" that did take place (e.g., Russia and China) is that nowhere has the ideology flourished where there was an advanced technological state. ${ }^{I}$ In one sense this is a rather damning pronouncement concerning the true nature of Marxism. On the other hand, it shows, once again, how an originally false definition of a situation evokes new behavior; thus fulfilling the terms of the originally false definition.

The Communist state is a definition of a political situation that has never really come to pass. Yet the revolutionaries in preindustrial China and Russia, initiated and carried through their respective revolutions as if they were based upon the original Marxian economic and political conditions. Tocay both Russia and China still continue to define their world and social roles as Marxian. The peculiarly false situations, which both derive their "Marxian" beginnings from are really unimportant in-so-far as this essay is concerned. All civilizations live on "selected fictions" which men call "ideals." That 
such "ideals" are in the main, "fictious" does not, however, make them superfluous or without value. Indeed, as Soviet and Chinese "Marxism" makes apparent, such definitions, whether or not they are attained in the ideal, are dynamic and emotion-filled mades. No one denies, certainly, that Marxism and Capitalism are "loaded" words, and if one inquires as to why they are "loaded" then he must come to grips with the way men define themselves and their world. But this means more than simply understanding a philosophy or philosophies. Ultimately it means understanding how men approach their futuce with regard to the world and themselves. For if a man cannot picture a philosophy, a social world, or a political structure as fully able of being realized in the real world (and in some not too distant future) then he will not act upon that vision. It is in the end, an almost too simple recognition of what every human being does in his own daily life. Each of us expects to live for a certain amount of time; and each of us to a certain extent fills in that "projected time" with certain plans. Is this not really making prophecy about ourselves? We certainly have no guarantee of the future, yet we all expect certain things. What the revolutionary does is simply adopt to a more definitive view of the future. The Marxists, as representative of the revolutionary, assumes a surpassing mastery over fate because he claims to know the pattern of history, and the inevitable. Everything he does will, as such, be defined and delineated in terms of this assumption. Even when events transpire differently the revolutionary Marxist will probably interpret them as part of the process of the dynamics of history. Herein lies his strength. Chairman Mao Tse-tung of the Chinese People's Republic 
for example, apparently viewed many of the setbacks to the eventual revolutionary victory of 1949 as almost necessary: as fulfilling the process of the dialectic. ${ }^{2}$ Action and reaction then are defined by the manner in which an individual approaches the future. Things may, of course, "pile up" and simply make all definitions of a particular future irrelevant. The revolutionary Marxist may finally encounter too much to cope with and be submerged in the currents of history. Men (as in the case of Regis Debray and "Che" Guevara). who consider man master of his own fate, may misread and misdirect the conduct and course of affairs. Sometimes even a million men cannot move one idea.

Man, as a whole, is certainly aware of the role of political and philosophical activity as a motivating factor in the affairs of nations and individuals. What may be lost on many is the role that expectations (i.e., prophecy) have in relation to motivation. Merleau Ponty, the French "political" philosopher has said, "Elle/La Politique/n'est pas une chapitre d'une histoire universelle deja écrite. E1le est une action qui s'invente." One might add, however, that while there is no "histoire universelle deja écrite", there are "invented" pictures of possible futures which as prophecy, tend, through the activity of men, to realize themselves. In other words, the only views of the future that will come to pass as "already written" are those that man insures through the acts of his own will; Marxist's not excepted. "Les grands revolutionnaires . . ," writes Merleau Ponty, "savent bien que I'histoire universelle n'est pas á contempler, mais á faire. ..." 